\title{
Aortic valve replacement with a novel anti-calcification technology platform
}

\author{
Jerzy Sadowski ${ }^{1 *}$, Krzysztof Bartuś ${ }^{1 *}$, Bogusław Kapelak ${ }^{1}$, Amy Chung $^{2}$, Maciej Stąpor ${ }^{1}$, Maciej Bochenek ${ }^{1}$ \\ 'Department of Cardiovascular Surgery and Transplantation, Jagiellonian University, John Paul II Hospital, Krakow, Poland \\ 2Edwards Lifesciences LLC, Irvine, California, United States \\ *The authors Jerzy Sadowski and Krzysztof Bartuś contributed equally to the preparation of this manuscript.
}

\begin{abstract}
Background and aim: The primary cause of long-term failure of bioprosthetic valves is structural valve deterioration due to tissue calcification. A novel anti-calcification technology platform was developed that may irreversibly block calcium binding sites in bioprosthetic valves.

Methods: Twenty patients with severe aortic stenosis underwent isolated aortic valve replacement using a bioprosthetic valve treated with the novel anti-calcification technology. Mean patient age and body mass index was $73.7 \pm 4.8$ years and $30.1 \pm 5.8 \mathrm{~kg} / \mathrm{m}^{2}$, respectively. Females comprised $65 \%$ of the patient population, and $30 \%$ of the population was in New York Heart Association class III/IV. Other baseline characteristics included hypertension (90\%), hyperlipidaemia (75\%), diabetes (35\%), renal failure (25\%), pulmonary disease (10\%), and myocardial infarction $(10 \%)$. Patients were followed-up for up to one year. Haemodynamic performance was evaluated by echocardiography. All complications were recorded.

Results: There was one early death on postoperative day five. No other complications were noted up to discharge. Follow-up at 3-6 months and at one year were both $100 \%$. At one year, no valve-related mortality, structural valve deterioration, major paravalvular leak $(>2+)$, thromboembolic events, major bleeding, prosthetic valve endocarditis, or reoperation were observed. Mean effective orifice area increased from $1.0 \pm 0.5 \mathrm{~cm}^{2}$ at baseline to $1.8 \pm 0.5 \mathrm{~cm}^{2}$ at one year. Mean gradient decreased from $54.8 \pm 21.2 \mathrm{~mm} \mathrm{Hg}$ at baseline to $11.3 \pm 3.4 \mathrm{~mm} \mathrm{Hg}$ at one year.

Conclusions: This early clinical experience using an aortic bioprosthetic valve treated with a novel anti-calcification tissue processing technology demonstrated excellent valve performance, durability, and safety. No valve-related complications were noted. Longer-term follow-up is needed to verify these promising results.
\end{abstract}

Key words: aortic valve replacement, anti-calcification treatment

Kardiol Pol 2015; 73, 5: 317-322

\section{INTRODUCTION}

Aortic valve stenosis (AS) is the most common form of valvular heart disease in the Western World and accounts for $43 \%$ of all patients with valvular heart disease [1, 2]. AS leads to greater mortality and morbidity compared to all other cardiac valve disease. Without treatment, patient survival is limited (2-3 years) following the onset of symptoms [3, 4]. Although AS prevalence increases with age, a wide range of patients at various ages are affected [5].

Two main categories of prostheses for aortic valve replacement (AVR) are available: mechanical and bioprosthetic tissue valves. In the past, younger patients ( $<65$ years old) were recommended mechanical valves owing to valve durability [6]. However, all mechanical valves required anti-coagulation over the lifespan of the patient. Anticoagulation treatment might lead to severe bleeding complications.

For younger patients, and especially younger female patients with a potential of pregnancy in the future, an anti-coagulation regimen is not a viable option $[7,8]$. Bioprostheses have the advantage of requiring limited or no anti-coagulation, but the challenge of durability remains an area of development $[9,10]$.

The primary cause of long-term valve failure is structural valve deterioration (SVD), and it is the most common

\section{Address for correspondence:}

Krzysztof Bartuś, MD, PhD, Assoc. Prof., Department of Cardiovascular Surgery and Transplantation, Jagiellonian University, John Paul II Hospital, ul. Prądnicka 80, 31-202 Kraków, Poland, tel: +48 126143 075, fax: +48 124233 900, e-mail: krzysztofbartus@gmail.com

Received: 13.08.2014 Accepted: 18.09.2014 Available as AoP: 28.10.2014

Copyright (C) Polskie Towarzystwo Kardiologiczne 
valve-related complication for bioprosthetic valves. The underlying root cause of SVD lies in calcium deposition onto the bioprosthesis, which leads to cuspal stiffening and often pure stenosis. Additionally, the occurrence of acute aortic insufficiency has been reported as progressive forms of calcific SVD and can result in tears in the leaflet tissue of some types of bioprostheses [11]. To prolong durability and to mitigate the impact of SVD by inhibiting calcium deposition onto the bioprosthesis, anti-calcification treatments for bioprosthetic tissue have been developed in the past $[12,13]$. However, the onset of bioburden and the subsequent SVD still remains unresolved, and the average lifetime of a bioprosthesis remains in the range of $10-20$ years $[11,14,15]$. To prolong the bioprosthetic lifespan by preventing calcific SVD, a novel tissue processing technology has been developed that may block calcium from binding to sites within the tissue.

This manuscript reports the one-year outcomes of the early feasibility cohort in AVR subjects receiving an aortic valve treated with the novel tissue process. Endpoints related to valve performance, durability, and safety are reported.

\section{METHODS}

\section{Patients}

Between July 2011 and September of 2011, 20 patients with predominant severe aortic stenosis and often with concomitant insufficiency underwent conventional AVR using a bioprosthetic valve treated with the novel anti-calcification technology (Model 11000, Edwards Lifesciences, LLC). This prospective, single-centre confirmatory clinical trial (clinicaltrials.gov \#NCT01651052) was sponsored by Edwards Lifesciences, LLC. The study was performed under Jagiellonian University Ethics Committee approval and Polish Ministry of Health agreement.

Patients with aortic valve disease requiring a planned replacement with or without concomitant coronary bypass surgery were enrolled in the study with written consent. Patients were excluded if they met any of the following criteria: aortic valve surgery is emergent; left ventricular ejection fraction is $<25 \%$; active endocarditis; concomitant valve (mitral, tricuspid, or pulmonic) disease; prior concomitant valve surgery; recent history of myocardial infarction; previous study device implant; history of drug abuse; pregnant; or part of another study. The primary safety endpoints of this study were those identified by the Objective Performance Criteria (ISO 5840:2005-Cardiovascular Implants-Cardiac Valve Prostheses): valve-related mortality, thromboembolic events, valve thrombosis, major bleeding events, major paravalvular leak $(>2+)$, endocarditis, SVD, haemolysis, and valve-related reoperation. Performance endpoints for this included short-term and long-term regurgitation, patient New York Heart Association (NYHA) functional class, and haemodynamic performance. Haemodynamic performance was evaluated by echocardiography as assessed by an independent echocardiographic core laboratory (RadCore Labs, Torrance, CA). Patients were followed at discharge, 30 days, 3-6 months, and one year.

\section{Study device}

The aortic valve Model 11000 is a trileaflet bioprosthesis comprised of bovine pericardium, treated with a novel tissue processing technique that provides anti-calcification efficacy [16, 17]. This anti-calcification technology builds upon the existing tissue treatment, the ThermaFix Process (TFX) (Edwards Lifesciences, LLC), which utilises buffered glutaraldehyde and formaldehyde-ethanol-Tween 80 solution (FET) for tissue fixation, sterilisation, and bioburden reduction. Additional elements of the novel tissue processing technique include capping, reduction, ethylene oxide sterilisation, and glycerolisation. For the purposes of further discussion, the novel tissue processing technique will be described as the technology platform and referred to as GLX [18]. Capping of functional groups such as aldehydes and free acids and reducing the remaining Schiff base sites reduces the potential sites for binding of calcium, phosphates, and immunogenic factors has been reported [19]. The glycerolisation treatment inhibits oxidation of the tissue, allowing for non-liquid storage and preservation of the structural integrity of the collagen matrix in the tissue valve. In this study, the aortic bioprosthesis size ranges from 21 to $27 \mathrm{~mm}(21,23$, 25 , and $27 \mathrm{~mm}$ ).

\section{Operative procedure}

The AVR procedure was performed via full or partial sternotomy according to previously described techniques [20]. After standard aortotomy (hockey-stick shaped), the diseased aortic valve was excised and annulus debrided. Very aggressive calcium debridement was performed in all cases. After annular dimension was assessed with a valve sizer, the appropriately sized bioprosthesis was selected and implanted in a supra-annular position and the aortotomy closed. No rinsing of the study valve was needed due to the fact the valves were supplied dry.

\section{Statistical analysis}

Continuous variables are summarised as mean and standard deviation while categorical variables are summarised as the number and percentage of patients in each category. For statistical comparison of the continuous data, an unpaired $t$-test was performed to compare the means over time. Early ( $\leq 30$ postoperative days) and late ( $>30$ postoperative days) complications and safety endpoints were adjudicated by an independent Clinical Endpoints Committee. Aggregate data were reviewed by an independent Data Safety Monitoring Board. 
Table 1. Patient baseline characteristics

\begin{tabular}{lc|} 
Parameter & $\begin{array}{c}\text { Percentage (n) } \\
\text { or mean } \pm \text { SD } \\
\text { (min-max) }\end{array}$ \\
\hline Age [years] & $73.7 \pm 4.8(63.0-82.0)$ \\
Gender/sex: female & $13(65.0 \%)$ \\
Body mass index & $30.1 \pm 5.8(22.3-40.9)$ \\
NYHA class: & \\
I & $4(20.0 \%)$ \\
II & $10(50.0 \%)$ \\
III/IV & $6(30.0 \%)$ \\
Medical history: & \\
Systemic hypertension & $18(90 \%)$ \\
Hyperlipidaemia/hypercholesterolaemia & $15(75 \%)$ \\
Coronary artery disease & $10(50 \%)$ \\
Rheumatic fever & $5(25 \%)$ \\
Myocardial infarction & $2(10 \%)$ \\
Smoker (past or current) & $3(15 \%)$ \\
Cerebrovascular disease & $1(5 \%)$ \\
\hline
\end{tabular}

NYHA — New York Heart Association; SD — standard deviation

\section{RESULTS}

Follow-up at discharge, 3-6 months, and at one year were $100 \%$. The baseline characteristics of the study group are presented in Table 1.

Technical success was achieved in $100 \%$ (20/20) of the patients. Isolated AVR comprised the majority of the procedures $(95 \%, 19 / 20)$ with only one patient undergoing AVR with a concomitant coronary artery bypass grafting (1 patient) procedure. Five (25\%) patients underwent AVR via upper hemisternotomy. Mean cross clamp time and cardiopulmonary bypass time were $59.6 \pm 10.3 \mathrm{~min}$ and $100.4 \pm 22.3 \mathrm{~min}$, respectively (Table 2 ).

One early death occurred on post-operative day five following respiratory distress and cardiac arrest, which was adjudicated as being related to the index procedure. One permanent pacemaker was implanted due to the development of atrioventricular block III. This patient demonstrated a left bundle branch block at baseline. No incidents of valve-related mortality, SVD, major paravalvular leak $(>2+)$, thromboembolic events, major bleeding, prosthetic valve endocarditis, or reoperation were observed up to one year. NYHA functional class was improved or remained the same in $84.2 \%(16 / 19)$ of the patient population, when comparing class change from baseline to one year.

Haemodynamic performance was improved from baseline to one year. Mean gradient for all valve sizes decreased from $54.8 \pm 21.2 \mathrm{~mm} \mathrm{Hg}$ at baseline to $11.3 \pm 3.4 \mathrm{~mm} \mathrm{Hg}$ at one year. Significant increases were
Table 2. Operative outcomes

\begin{tabular}{|lc|}
\hline Parameter & $\begin{array}{c}\text { Percentage (n) } \\
\text { or mean } \pm \text { SD } \\
\text { (min-max) }\end{array}$ \\
\hline Aetiology: & \\
Congenital & $2(10.0 \%)$ \\
Degenerative & $10(50.0 \%)$ \\
Dystrophic calcification & $2(10.0 \%)$ \\
Rheumatic & $6(30.0 \%)$ \\
Valve size implanted [mm]: & \\
21 & $8(40.0 \%)$ \\
23 & $9(45.0 \%)$ \\
25 & $2(10.0 \%)$ \\
27 & $1(5.0 \%)$ \\
Surgical approach: & \\
Full sternotomy & $15(75.0 \%)$ \\
Upper hemi sternotomy & $5(25.0 \%)$ \\
Cardiopulmonary bypass time [min] & $100.4 \pm 22.3(69-155)$ \\
Cross clamp time [min] & $59.6 \pm 10.3(43-78)$ \\
Length of stay [days] & $9.5 \pm 3.7(7-20)$ \\
\hline SD - standard deviation &
\end{tabular}

observed for the 21 and $23 \mathrm{~mm}$ valves from baseline to one year $(p<0.0001$ and $p<0.0013$, respectively). Mean effective orifice area for all valve sizes increased $1.0 \pm 0.5 \mathrm{~cm}^{2}$ at baseline to $1.8 \pm 0.5 \mathrm{~cm}^{2}$ at one year. Significant increases were observed for the $21-\mathrm{mm}$ and $25-\mathrm{mm}$ valves from baseline to one year ( $p<0.0009$ and $p<0.0125$, respectively) (Table 3).

\section{DISCUSSION}

The treatment for aortic stenosis began over 60 years ago, starting with mechanical valves [21]. While mechanical valves offered high durability, intense life-long anti-coagulation requirements led to the research and development of tissue valves $[22,23]$. Over the past six decades, a large number of prosthetic heart valves have been under intense research and development.

Though valve design enhancements to reduce material fatigue (e.g. design changes to apply net zero pressure on the leaflet, lowered stent post and base profile to minimise protrusion, and development of thinner, more flexible valve stents) have been developed, the bioprosthetic tissue source, as well as tissue processing technologies, has also undergone significant development.

The first generation of bioprostheses consisted of tissue valves from porcine, fixed in formalin. In the late 1960s, formalin-fixation was replaced by a far more stable glutaraldehyde cross-linking technique, which provided anti-immu- 
Table 3. Haemodynamic performance

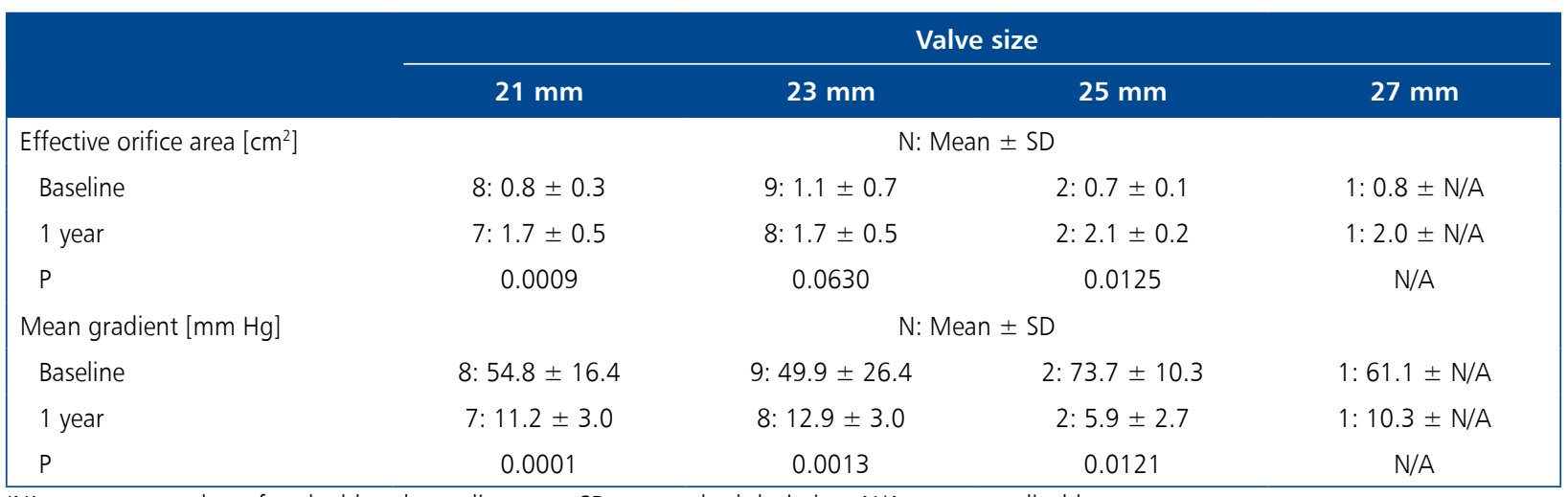

' $\mathrm{N}$ ' represent number of evaluable echocardiograms; SD — standard deviation; N/A — not applicable

nological and anti-degenerative tissue material [24]. However, a common problem with glutaraldehyde treatment of tissue that remains an area of development to date is the residual aldehydes, free acids, and Schiff bases that are by-products of the tissue fixation process. These functional groups serve as potential binding sites for calcium, phosphates, and immunogenic agents that contribute to the deterioration of the valve. Attempts to reduce bioburden by capping these functional groups with various agents (proteins, amino acids, or amines) have been proposed, but these agents are not permanent as they diffuse out of the tissue over time [25, 26].

Recently, a technique to remove unstable glutaraldehyde residuals through a combination of both thermal and chemical agents was developed. This tissue process, TFX, applied to bovine pericardial valves has demonstrated excellent clinical safety and durability $[27,28]$. To further enhance the TFX technology for prolonged valve durability, a novel anti-calcification technology platform was created to irreversibly cap the aldehyde groups through reductive amination [17]. The technology platform, GLX, introduces the additional step of capping, reducing, and glycerolisation, thereby eliminating sites that would otherwise be exposed as potential binding sites for calcium, phosphate, and immunogenic agents [18]. In addition, the GLX process allows for non-liquid storage, inhibiting oxidation in of the tissue and prolonging the lifetime of the tissue. When comparing the anti-calcification efficacy in a rabbit intramuscular implant study, the GLX processed pericardial tissue demonstrated a 93\% reduction in calcium content compared to the TFX-processed pericardial tissue at 35 days [18].

These promising findings led to further investigation in the clinical setting, and this report demonstrates the one-year clinical outcomes of a bioprosthetic valve treated with the novel anti-calcification GLX technology platform. This initial clinical experience with a GLX-treated valve in the aortic position demonstrated excellent valve performance and safety. The study showed complete freedom from the primary endpoints. Additionally, significant improvement in NYHA class and in haemodynamic performance up to one year was observed.

This initial clinical experience demonstrates safety, efficacy, and feasibility with an enhanced bioprosthetic valve for prolonged durability. With increased life expectancies, durable bioprosthetic options such as these are critical for both younger and elderly patients undergoing bioprosthetic AVR [1, 29]. Additionally, options for younger patients ( $<60$ years), which represent a growing subset of the AVR candidate population, need further focus and development. As tissue valve durability has been increasing and the mean age of AVR patients has increased, the recommended age for AVR with bioprosthesis was recently lowered from patients aged 65 years or older to patients aged 60 years or older by the American Heart Association and the American College of Cardiology [6]. This places further importance on valve durability research and development as the under-appreciated area of valvular heart disease represents a growing public-health concern affecting an increasingly wide span of patients. The novel anti-calcification technology platform described in this study shows promising initial clinical outcomes, and additional enrolment and longer-term follow-up is ongoing to verify these results.

\section{Limitations of the study}

The present study was a non-randomised, single-arm study. A concurrent control group was not studied in this clinical trial. Additional limitations include a small patient cohort and a follow-up period that extends only to one year. Long-term performance and complications need to be examined to test the durability of the valve for which the prosthesis was designed. Much larger cohorts should be investigated with the use of this novel anti-calcification tissue processing technology.

\section{CONCLUSIONS}

This early clinical experience using an aortic bioprosthetic valve treated with a novel anti-calcification tissue processing tech- 
nology demonstrated excellent valve performance, durability, and safety at one year. Additional enrolment and longer-term follow-up is ongoing to verify these promising results.

Conflict of interest: The clinical study was supported by Edwards Lifesciences.

\section{References}

1. Grimard B, Larson J. Aortic stenosis: diagnosis and treatment. Am Fam Physician, 2008; 78: 717-724.

2. Roberts W, Ko J. Frequency by decades of unicuspid, bicuspid, and tricuspid aortic valves in adults having isolated aortic valve replacement for aortic stenosis, with or without associated aortic regurgitation. Circulation, 2005; 111: 920-925.

3. Iivanainen A, Lindroos M, Tilvis R et al. Natural history of aortic valve stenosis of varying severity in the elderly. Am J Cardiol, 1996; 78: 97-101.

4. Bach D, Siao D, Girard S et al. Evalation of patients with severe symptomatic aortic stenosis who do not undergo aortic valve replacement: the potential role of subjectively overestimated operative risk. Circ Cardiovasc Qual Outcomes, 2009; 2: 533-539.

5. Davies M, Treasure T, Parker D. Demographic characteristics of patients undergoing aortic valve replacement for stenosis: relation to valve morphology. Heart, 1996; 75: 174-178.

6. Bonow R, Carabello B, Chatterjee K et al. ACC/AHA 2006 Guidelines for the Management of Patients With Valvular Heart Disease. A Report of the American College of Cardiology/American Heart Association Task Force on Practice Guidelines (Writing Committee to Revise the 1998 Guidelines for the Management of Patients With Valvular Heart Disease) Developed in Collaboration With the Society of Cardiovascular Anesthesiologists Endorsed by the Society for Cardiovascular Angiography and Interventions and the Society of Thoracic Surgeons. J Am Coll Cardiol, 2006; 48: e1-e148.

7. Reimold S, Rutherford J. Clinical practice: valvular heart disease in pregnancy. N Engl J Med, 2003; 349: 52-59.

8. Elkayam U, Bitar F. Valvular heart disease and pregnancy, part II: prosthetic valves. J Am Coll Cardiol, 2005; 46: 403-410.

9. Zilla P, Brink J, Human P, Bezuidenhout D. Prosthetic heart valves: catering for the few. Biomaterials, 2008; 29: 385-406.

10. Nishida R, Tominaga R. A look at recent improvements in the durability of tissue valves. Gen Thorac Cardiovasc Surg, 2013; 61: 182-190.

11. Grunkemeier G, Furnary A, Wu Y et al. Durability of pericardial versus porcine bioprosthetic heart valves. J Thorac Cardiovasc Surg, 2012; 144: 1381-1386.

12. Chen W, Schoen F, Levy R. Mechanism of efficacy of 2-amino oleic acid for inhibition of calcification of glutaraldehyde pre-treated porcine bioprosthetic heart valves. Circulation, 1994; 90: 323-329.

13. Schoen F, Levy R. Calcification of tissue heart valve substitutes: Progress toward understanding and prevention. Ann Thorac Surg, 2005; 79: 1072-1080.

14. Grunkemeier G, Li H, Naftel D et al. Long-term performance of heart valve prostheses. Curr Opin Cardiol, 2000; 25: 73-154.

15. Rahimtoola S. Choice of prosthetic heart valves in adults. J Am Coll Cardiol, 2010; 55: 2413-2426.

16. Totaro P, Degno N, Zaidi A et al. Carpentier-Edwards PERIMOUNT Magna bioprosthesis: a stented valve with stentless performance? J Thorac Cardiovasc Surg, 2005; 130: 1668-1674.

17. Carpentier A, Carpentier S, Cunanan C et al. Inventors; Edwards Lifesciences Corporation, Assignee. Treating biological tissues to mitigate post-implantation calcification. United States 2007.

18. Dove J, Dobler D, Davidson J, Wright G. Inventors; Edwards Lifesciences Corporation, Assignee. Capping bioprosthetic tissue to reduce calcification. United States 2009.

19. Munnelly A, Schoen F, Vyavahare N. Biomaterial calcification: mechanisms and prevention. degradation of implant materials. Springer, New York 2012.

20. David T. Surgery of the aortic valve. Curr Prob Surgery, 1999; 36: 421-501.

21. Matthews A. The development of the Starr-Edwards heart valve. Texas Heart Institute J, 1998; 25: 282-293.

22. Shiono M, Sezai Y, Sezai A et al. Long-term results of the cloth-covered Starr-Edwards ball valve. Ann Thoracic Surg, 2005; 80: 204-209.

23. Gao G, Wu Y, Grunkemeier G et al. Forty-year survival with the Starr-Edwards heart valve prosthesis. J Heart Valve Disease, 2004; 13: 91-96.

24. Carpentier A, Lemaigre G, Robert L et al. Biological factors affecting long-term results of valvular heterografts. J Thorac Cardiovasc Surg, 1969; 58: 467-483.

25. Cheung D. Inventor; Mitroflow International, Inc, Assignee. Borohydride reduction of biological tissues. United States 1999.

26. Seifter E, Frater R. Inventors; Albert Einstein College of Medicine of Yeshiva University, Assignee. Anticalcification treatment for aldehyde-tanned biological tissue. United States 1995.

27. Aupart M, Mirza A, Meurisse Y et al. 20 years' durability of Carpentier-Edwards Perimount stented pericardial aortic valve. In Aortic Root Surgery, 2010; 441-51.

28. Jamieson W, Germann E, Aupart MR et al. 15-Year comparison of supra-annular porcine and PERIMOUNT aortic bioprostheses. Asian Cardiovasc Thorac Ann. 2006; 14: 200-205.

29. Giannakouris K. Ageing characterises the demographic perspectives of the European societies. Statistics in Focus, 2008; 72. 


\title{
Wymiana zastawki aortalnej z nową antykalcyfikacyjną platformą technologiczną
}

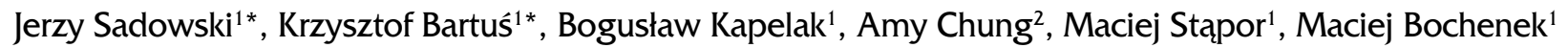 \\ ${ }^{1}$ Klinika Chirurgii Serca Naczyń i Transplantologii, Collegium Medicum, Uniwersytet Jagielloński, Kraków \\ ${ }^{2}$ Edwards Lifesciences LLC, Irvine, Kalifornia, Stany Zjednoczone
}

*Autorzy Jerzy Sadowski i Krzysztof Bartuś w jednakowym stopniu przyczynili się do powstania niniejszej pracy.

\section{Streszczenie}

Wstęp i cel: Główną przyczyną odległych uszkodzeń zastawki aortalnej są uszkodzenia strukturalne spowodowane zwapnieniem tkanek. Nowa platforma technologiczna antykalcyfikacji została opracowana w ten sposób, by nieodwracalnie blokować miejsca wiązania wapnia w zastawkach biologicznych.

Metody: Dwudziestu pacjentów z ciężką stenozą aortalną zostało poddanych operacji wymiany zastawki aortalnej z użyciem biologicznej zastawki aortalnej traktowanej nową technologią antykalcyfikacyjną. Średni wiek pacjentów i wskaźnik masy ciała wynosiły odpowiednio $73,7 \pm 4,8$ roku i $30,1 \pm 5,8 \mathrm{~kg} / \mathrm{m}^{2}$. Kobiety stanowiły $65 \%$ populacji, a $30 \%$ chorych było w klasie III lub IV wg NYHA. Nadciśnienie tętnicze stwierdzono u 90\% pacjentów, hiperlipidemię - u 75\%, cukrzycę - u 35\%, niewydolność nerek - u 25\%, choroby płuc - u 10\%, a zawał serca - u 10\% osób. Pacjenci byli obserwowani do 1 roku od operacji. Zastawki oceniano hemodynamicznie na podstawie badania echokardiograficznego. Odnotowywano wszystkie powikłania. Wyniki: Stwierdzono 1 wczesny zgon bez związku z zastawką w 5. dobie. Nie odnotowano żadnych innych powikłań do momentu wypisu ze szpitala. Kontrolę pooperacyjną po 3-6 miesiącach i po 1 roku przeprowadzono u 100\% pacjentów. Po roku nie stwierdzono zgonu związanego z zastawką, uszkodzeń strukturalnych zastawki, przecieku okołozastawkowego $(>2+)$, zdarzeń zakrzepowo-zatorowych, poważnego krwawienia, zapalenia wsierdzia i nie wykonano reoperacji. Średnia efektywna powierzchnia ujścia zwiększyła się z 1,0 $\pm 0.5 \mathrm{~cm}^{2}$ na początku badania do $1,8 \pm 0,5 \mathrm{~cm}^{2}$ po roku. Średni gradient zmniejszył się z 54,8 \pm 21,2 mm Hg na początku badania do 11,3 $\pm 3,4 \mathrm{~mm} \mathrm{Hg}$ po roku.

Wnioski: Wczesne doświadczenia kliniczne z zastosowaniem bioprotezy aortalnej traktowanej nową technologią antykalcyfikacji i przetwarzania tkanek wskazują na jej doskonałą wydajność, trwałość i bezpieczeństwo. Nie zaobserwowano powikłań związanych z użytą zastawką. Konieczna jest długoterminowa obserwacja w celu zweryfikowania tych obiecujących wyników. Słowa kluczowe: wymiana zastawki aortalnej, terapia antykalcyfikacyjna

Kardiol Pol 2015; 73, 5: 317-322

\section{Adres do korespondencji:}

dr hab. n. med. Krzysztof Bartuś, Klinika Chirurgii Serca Naczyń i Transplantologii, Collegium Medicum, Uniwersytet Jagielloński, ul. Prądnicka 80, $31-202$ Kraków, tel: +48 126143 075, faks: +48 124233 900, e-mail: krzysztofbartus@gmail.com

Praca wpłynęła: 13.08.2014 r. Z Zaakceptowana do druku: 18.09.2014 r.

Data publikacji AoP: 28.10.2014 r. 